\title{
Trigonostemon reidioides modulates endothelial cell proliferation, migration and tube formation via downregulation of the Akt signaling pathway
}

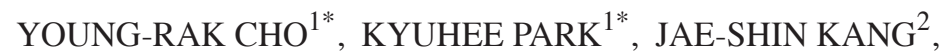 \\ HYE-WOO BYUN ${ }^{2}$, JOA SUB OH ${ }^{3}$, DONG-WAN SEO ${ }^{3}$ and EUN-KYUNG AHN ${ }^{1}$ \\ ${ }^{1}$ Bio-Center, Gyeonggi Institute of Science and Technology Promotion, Suwon, Gyeonggi 16229; \\ ${ }^{2}$ Biological Genetic Resources Utilization Division, National Institute of Biological Resources, Seo, Incheon 22689; \\ ${ }^{3}$ Department of Pharmacy, College of Pharmacy, Dankook University, Cheonan, Chungcheong 31116, Republic of Korea
}

Received June 13, 2016; Accepted March 7, 2017

DOI: $10.3892 / \mathrm{ol} .2017 .6760$

\begin{abstract}
Trigonostemon reidi oides (TR) is used as a Thai traditional medicine for the treatment of drug addiction, asthma, food poisoning, constipation and snake bites. The present study investigated the effects and molecular mechanisms of the ethanolic extract of TR (ETR) on mitogen-induced human umbilical vein endothelial cells (HUVECs) responses, proliferation, adhesion, migration and tube formation. ETR treatment inhibited mitogen-induced HUVEC proliferation by downregulation of cell cycle-associated proteins, including cyclins and cyclin-dependent kinases, which induced retinoblastoma protein hypophosphorylation. The present study also demonstrated that ETR treatment suppressed mitogen-induced HUVEC adhesion, migration, invasion and tube formation, and that these anti-angiogenic activities were mediated by inactivation of mitogen-induced Akt and matrix metalloproteinase (MMP)-2, but not of extracellular signal-regulated kinase, p70 ribosomal S6 kinase or MMP-9. Collectively, the results of the present study suggested pharmacological
\end{abstract}

Correspondence to: Dr Eun-Kyung Ahn, Bio-Center, Gyeonggi Institute of Science and Technology Promotion, 147 Gwanggyo-ro, Suwon, Gyeonggi 16229, Republic of Korea

E-mail: aek@gstep.re.kr

${ }^{*}$ Contributed equally

Abbreviations: Cdks, cyclin-dependent kinases; EBM-2, endothelial basal medium-2; ERK, extracellular signal-regulated kinase; ETR, ethanolic extract of Trigonostemon reidioides; HUVECs, human umbilical vein endothelial cells; MMPs, matrix metalloproteinases; mTOR, mammalian target of rapamycin; PI3K, phosphatidylinositol 3-kinase; pRb, retinoblastoma protein; p70S6K, p70 ribosomal S6 kinase; VEGF-A, vascular endothelial growth factor-A

Key words: Trigonostemon reidioides, Akt, matrix metalloproteinase-2, angiogenesis functions and molecular mechanisms of ETR in regulating endothelial cell fates, and supported further evaluation and development of ETR as a potential therapeutic agent for the treatment and prevention of angiogenesis-associated diseases, including cancer.

\section{Introduction}

Angiogenesis, which is the formation, recruitment and growth of new blood capillaries from existing neighboring vasculature, is known to serve important roles in pathological conditions, including cancer growth, progression, rheumatoid arthritis and diabetic retinopathy $(1,2)$. Angiogenesis is associated with the stimulation of endothelial cell proliferation, migration, adhesion, invasion and tube formation by a variety of angiogenic and anti-angiogenic factors, and is regulated by a variety of signaling pathways within the tissue microenvironment $(3,4)$. Numerous angiogenic factors such as vascular endothelial growth factor (VEGF)-A and subsequent signaling pathways, including extracellular signal-regulated kinase (ERK), phosphatidylinositol 3-kinase (PI3K)/Akt and p70 ribosomal S6 kinase (p70S6K), stimulate endothelial cells, thus inducing cell proliferation, migration and survival, indicating that these factors may be targeted as a therapeutic strategy for a variety of angiogenesis-associated diseases (5-8).

PI3K/Akt, one of the key signaling enzymes in cell mitogenesis, is closely associated with various types of cell growth, cell survival and cancer progression $(9,10)$. The serine/threonine kinase Akt is activated by a PI3K-dependent signaling pathway and serves a pivotal role in angiogenesis $(11,12)$. A previous study demonstrated that the PI3K/Akt signaling pathway promoted retinal angiogenesis by cooperation with cysteine-rich protein 61 in retinopathy of prematurity $(13,14)$. In addition, the PI3K/Akt signaling pathway is essential to hypoxia-induced expression of hypoxia-inducible factor-1a and VEGF in choroidal neovascularization (12). Inhibition of the PI3K/Akt pathway usually results in substantial antitumor and anti-angiogenic effects (15-17), indicating that targeting PI3K/AKT may be a strategy for blocking angiogenesis-associated diseases. 
Trigonostemon reidioides (TR) Craib (Euphorbiaceae) has been used as a Thai traditional medicine for the treatment of drug addiction, asthma, food poisoning, constipation and snake bites (18). TR is a native species to Southeast Asia, including Vietnam, Cambodia and Myanmar (19). Numerous previous studies have demonstrated that the bioactive compounds of TR have cytotoxic activity against a number of cell lines, including bile duct cancer, cervical cancer and liver cancer cell lines $(20,21)$; however, the effects and signaling pathways of the ethanolic extract of TR (ETR) on angiogenesis remain unknown. Therefore, the present study evaluated the effects and molecular mechanisms of ETR on cell proliferation, adhesion, migration, invasion and tube formation in human umbilical vein endothelial cells (HUVECs).

\section{Materials and methods}

Cell culture conditions. Primary cultures of HUVECs were purchased from Lonza (Walkersville, MD, USA) and used between passages 4 and 6 for all experiments. Cells were cultured in EGM- $2{ }^{\circledR}$ BulletKit medium, containing endothelial basal medium-2 (EBM-2) and growth supplements (EGM-2 ${ }^{\circledR}$ SingleQuots kit, human epidermal growth factor, VEGF, R3-insulin-like growth factor-1, human fibroblast growth factor, ascorbic acid, hydrocortisone, heparin, fetal bovine serum and gentamicin/amphotericin B), which was designated as complete medium. Cell culture was performed according to the manufacturer's protocol (Lonza).

Reagents. The following antibodies were purchased from commercial sources: Anti-phosphorylated (p)-ERK (T202/Y204; catalog no., 9101), anti-p-Akt (S473; catalog no., 4060), anti-p-p70S6K (T421/S424; catalog no., 9204), anti-retinoblastoma protein (pRb; S780; catalog no., 9307) and anti-p-pRb (S811; catalog no., 9308), which were all purchased from Cell Signaling Technology, Inc. (Danvers, MA, USA), and anti-ERK (catalog no., 9102), anti-Akt (catalog no., 9272), anti-cyclin-dependent kinase (Cdk) 4 (catalog no., sc-260), anti-Cdk2 (catalog no., sc-6248), anti-cyclin D (catalog no., sc-20044), anti-cyclin E (catalog no., sc-247) and anti- $\beta$-actin (catalog no., sc-47778) antibodies, in addition to mouse and rabbit immunoglobulin G-horseradish peroxidase conjugates, which were all purchased from Santa Cruz Biotechnology Inc. (Dallas, TX, USA).

Preparation of ETR. Dried TR (175 g) was pulverized and extracted using $70 \%$ ethanol for $24 \mathrm{~h}$ at room temperature. The extract was filtered and concentrated under vacuum at reduced pressure using a rotary flash evaporator (BÜCHI Labortechnik AG, Flawil, Switzerland), and ethanol was allowed to completely evaporate. The remaining aqueous solution was concentrated under vacuum and freeze dried (ilShinBioBase Co., Ltd., Dongducheon, Korea). The crude extract yield was $4 \%(\mathrm{w} / \mathrm{v})$.

Cell viability and proliferation assay. Subconfluent HUVECs were plated at a density of $1 \times 10^{5}$ cells/well on 6 -well plates (BD Biosciences, Franklin Lakes, NJ, USA) and serum-starved for $14 \mathrm{~h}$ at $37^{\circ} \mathrm{C}$ in EBM-2 medium to synchronize cells in the $\mathrm{G}_{1} / \mathrm{G}_{0}$ cell cycle phase, prior to incubation for $24 \mathrm{~h}$ at $37^{\circ} \mathrm{C}$ in
EGM-2 BulletKit medium in the presence or absence of ETR (1-25 $\mu \mathrm{g} / \mathrm{ml})$. Following incubation for $24 \mathrm{~h}$, cell viability was determined using an Invitrogen ${ }^{\mathrm{TM}}$ Countess $^{\mathrm{TM}}$ Automated Cell Counter (Thermo Fisher Scientific, Inc., Waltham, MA, USA). The results from triplicate determinations (mean \pm standard deviation) are presented as the numbers of cells per culture.

Western blot analysis. Quiescent HUVECs were plated at density of $1 \times 10^{6}$ cells/dish on 100-mm dishes (BD Biosciences), serum-starved for $14 \mathrm{~h}$ in EBM-2 medium and incubated for 15 min or $24 \mathrm{~h}$ at $37^{\circ} \mathrm{C}$ in EGM-2 BulletKit medium in the presence or absence of ETR (1-25 $\mu \mathrm{g} / \mathrm{ml})$. Cells were rinsed twice with ice-cold PBS and lysed by incubation in $50 \mathrm{mM}$ Tris- $\mathrm{HCl}$ (pH 7.4), $150 \mathrm{mM} \mathrm{NaCl}, 10 \%$ glycerol, $1 \%$ Triton $\mathrm{X}-100,1 \mathrm{mM}$ EDTA, $100 \mu \mathrm{g} / \mathrm{ml}$ 4-(2-aminoethyl)benzenesulfonyl fluoride, $10 \mu \mathrm{g} / \mathrm{ml}$ aprotinin, $1 \mu \mathrm{g} / \mathrm{ml}$ pepstatin A, $0.5 \mu \mathrm{g} / \mathrm{ml}$ leupeptin, $80 \mathrm{mM} \beta$-glycerophosphate, $25 \mathrm{mM}$ sodium fluoride and $1 \mathrm{mM}$ sodium orthovanadate for $30 \mathrm{~min}$ at $4^{\circ} \mathrm{C}$. Cell lysates were clarified at $12,500 \mathrm{x}$ g for $20 \mathrm{~min}$ at $4^{\circ} \mathrm{C}$, and the supernatants were subjected to western blot analysis as described previously $(22,23)$. Total protein was quantified with the Quick Start ${ }^{\mathrm{TM}}$ Bradford 1X Dye Reagent (Bio-Rad Laboratories, Inc., Hercules, CA, USA) using bovine serum albumin (BSA; Sigma-Aldrich; Merck KGaA, Darmstadt, Germany) for the standard. Protein extracts representing $40 \mathrm{mg}$ total protein were separated on $10 \%$ SDS-PAGE gel using the Bio-Rad Mini Protean 3 System (Bio-Rad Laboratories, Inc.) and electro-blotted onto Protran ${ }^{\circledR}$ nitrocellulose membranes (Sigma-Aldrich; Merck KGaA). Membranes were blocked in 5\% BSA in PBS/0.025\% Tween-20 (Sigma-Aldrich; Merck $\mathrm{KGaA}$ ) for $1 \mathrm{~h}$ at room temperature. The primary antibodies used were specific for p-ERK, ERK, p-Akt, Akt, p-p70s6k, p-pRb(S780), p-pRb(S811) (Cell Signaling Technology, Inc.) and Cdk4, Cdk2, cyclin D, cyclin E, $\beta$-actin (Santa Cruz Biotechnology, Inc.). The primary antibodies were diluted (dilution, 1:1,000) in 5\% BSA in PBST, and incubated with the membrane overnight at $4^{\circ} \mathrm{C}$. The secondary antibodies were applied at a 1:2,000 dilution in 5\% BSA in PBST and incubated for $1 \mathrm{~h}$ at room temperature, then processed for detection with the Supersignal West Pico Chemiluminescent Substrate (Thermo Fisher Scientific, Inc.), using the Amersham ${ }^{\mathrm{TM}}$ Imager 600 and Imaging Software (ver 0.4.4; GE Healthcare Life Sciences, Chalfont, UK). All western blot analyses are representative of $\geq 3$ independent experiments.

Migration assay. Cell migration was quantified via in vitro wound-healing assay as described previously (24). Following plating of cells on 48 -well plates $\left(4 \times 10^{4}\right.$ cells/well) and allowing them to grow to confluence, a single wound was created in the center of the cell monolayer by gentle removal of the attached cells using a sterile plastic pipette tip. Following serum starvation with EBM-2 for $2 \mathrm{~h}$ at $37^{\circ} \mathrm{C}$, cells were incubated for $16 \mathrm{~h}$ at $37^{\circ} \mathrm{C}$ in EGM-2 BulletKit medium in the presence or absence of ETR $(1-25 \mu \mathrm{g} / \mathrm{ml})$. Cells were fixed with methanol and then stained with $0.04 \%$ Giemsa solution (Sigma-Aldrich; Merck KGaA, Darmstadt, Germany). Migration of the cells into the wound was observed, and still images were captured following incubation for $16 \mathrm{~h}$. Images were captured using a Nikon Digital Sight DS-U1 microscope (Nikon Corporation, Tokyo, Japan). 

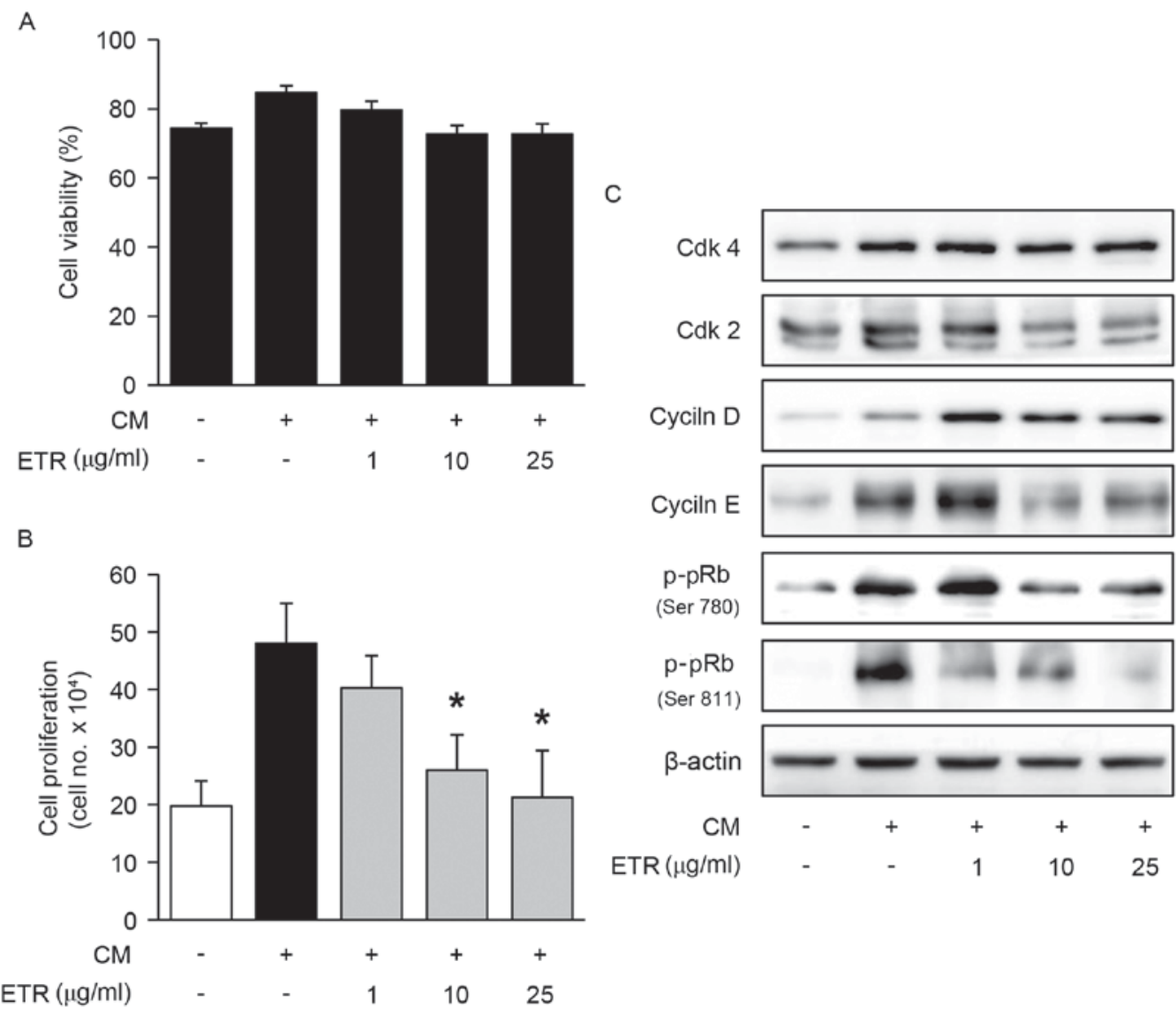

Figure 1. Anti-proliferative effect of ETR on mitogen-induced HUVECs is mediated by downregulation of cell cycle-associated proteins. (A) Cell viability of quiescent HUVECs incubated for $24 \mathrm{~h}$ in CM supplemented with growth factors with or without ETR $(1,10 \mathrm{and} 25 \mu \mathrm{g} / \mathrm{ml})$. (B) Cell proliferation of cells treated with $\operatorname{ETR}(1,10$ and $25 \mu \mathrm{g} / \mathrm{ml})$. The results from triplicate determinations (mean \pm standard deviation) are presented as the percentage of viable cells out of the total cell count. Statistical significance is indicated ( $\mathrm{P}<0.05$, compared with CM-treated cells). (C) Cell lysate expression levels were determined by western blotting with anti-Cdk4, anti-Cdk2, anti-cyclin D, anti-cyclin E, anti-p-pRb or anti- $\beta$-actin antibodies. Results are representative of $\geq 3$ independent experiments. ETR, ethanolic extract of Trigonostemon reidioides; HUVECs, human umbilical vein endothelial cells; CM, complete medium; Cdk, cyclin-dependent kinase; pRb, retinoblastoma protein.

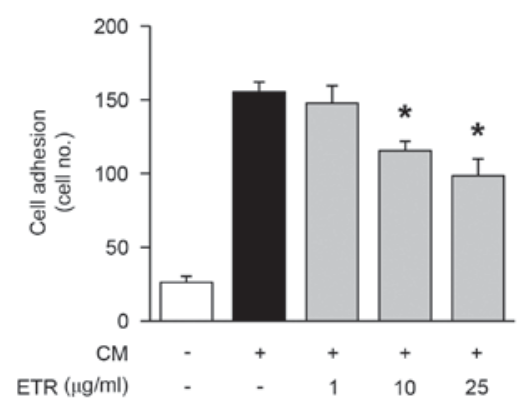

Figure 2. ETR inhibits mitogen-induced adhesion in human umbilical vein endothelial cells. Cells were incubated for $2 \mathrm{~h}$ in CM with or without ETR $(1,10$ and $25 \mu \mathrm{g} / \mathrm{ml})$. The number of adhered cells was determined by counting six fields of cells (magnification, x200). Results from six independent experiments (mean \pm standard deviation) are presented as the number of adhered cells. Statistical significance is indicated ( ${ }^{*} \mathrm{P}<0.05$, compared with CM-treated cells). ETR, ethanolic extract of Trigonostemon reidioides; CM, complete medium.

Invasion assay. The upper side of the Transwell insert $(6.5-\mathrm{mm}$ diameter insert, $8-\mu \mathrm{m}$ pore size; Corning Incorporated,Corning, NY, USA) was coated with $50 \mu \mathrm{l} 1 \mathrm{mg} / \mathrm{ml}$ Matrigel ${ }^{\circledR}$ basement membrane matrix (10.4 mg/ml; BD Biosciences) diluted in EBM-2. Aliquots $(100 \mu \mathrm{l})$ of HUVECs $\left(5 \times 10^{4}\right.$ cells $\left./ \mathrm{ml}\right)$ resuspended in EBM-2 were added to the upper compartment of the Matrigel-coated Transwell and $600 \mu \mathrm{l}$ EBM-2 was added to the lower compartment. Following serum starvation with EBM-2 for $2 \mathrm{~h}$, cells were incubated for $15 \mathrm{~h}$ at $37^{\circ} \mathrm{C}$ in EGM-2 Bullet kit media in the presence or absence of ETR $(1-25 \mu \mathrm{g} / \mathrm{ml})$. The inserts were fixed with $95-100 \%$ methanol (Merck KGaA, Darmstadt, Germany; \#106009.1011) and the non-invasive cells were removed from the top of the membrane using a cotton-tipped swab. Following staining with $0.04 \%$ Giemsa solution, the number of invasive cells was determined from six fields using x200 objective magnification. Images were captured using a Nikon Digital Sight DS-U1 microscope (Nikon Corporation).

Tube formation assays. Matrigel basement membrane matrix $\left(10.4 \mathrm{mg} / \mathrm{ml}\right.$; BD Biosciences) was thawed overnight at $4^{\circ} \mathrm{C}$, and each well of pre-chilled 24-well plates was coated with $200 \mu \mathrm{l}$ Matrigel and then incubated at $37^{\circ} \mathrm{C}$ for $30 \mathrm{~min}$. Following serum starvation with EBM-2 medium for $2 \mathrm{~h}$, cells $\left(4 \times 10^{4}\right.$ cells $/ \mathrm{ml}$ ) were added to Matrigel-coated plates and treated with ETR $(1-25 \mu \mathrm{g} / \mathrm{ml})$ for $6 \mathrm{~h}$ at $37^{\circ} \mathrm{C}$. Tube formation was observed using an inverted microscope (Eclipse TE2000-U; Nikon Corporation) and NIS-Elements F 3.0 software (Nikon Corporation). 
Zymogram analysis. Activities of matrix metalloproteinases (MMPs) were evaluated using zymography $(25,26)$. Aliquots of basic EBM 2 medium collected from HUVECs treated with ETR $(1-25 \mu \mathrm{g} / \mathrm{ml})$ for $16 \mathrm{~h}$ at room temperature were diluted in sample buffer (Bio-Rad Laboratories, Inc.; \#161-0764) and applied to $8 \%$ polyacrylamide gels supplemented with $1 \mathrm{mg} / \mathrm{ml}$ gelatin (Sigma-Aldrich; Merck KGaA) as a substrate. Following electrophoresis, the gels were incubated in $2.5 \%$ Triton $\mathrm{X}-100$ for $1 \mathrm{~h}$ at room temperature in order to remove SDS and allow re-naturalization of MMPs, and then further incubated in developing buffer (Bio-Rad Laboratories, Inc.; \#161-0766) supplemented with $50 \mathrm{mM}$ Tris- $\mathrm{HCl}$ (pH 7.5), $10 \mathrm{mM} \mathrm{CaCl}_{2}$ and $150 \mathrm{mM} \mathrm{NaCl}$ for $16 \mathrm{~h}$ at $37^{\circ} \mathrm{C}$. The gels were stained with $0.5 \%$ Coomassie Brilliant Blue R-250 in $30 \%$ methanol- $10 \%$ acetic acid for $3 \mathrm{~h}$, followed by de-staining with $30 \%$ methanol-10\% acetic acid. Gelatinolytic activities were detected as unstained bands against the background of the Coomassie Brilliant Blue R-250 Blue-stained gelatin.

Statistical analysis. Statistical analysis was performed by a Student's t-test using Microsoft Excel 2007 software (Microsoft Corporation, Redmond, WA, USA). Results are presented as the mean \pm standard deviation. $\mathrm{P}<0.05$ was considered to indicate a statistically significant difference.

\section{Results}

ETR inhibits endothelial cell proliferation by regulating the expression level of cell cycle-associated proteins. To investigate the effects of ETR on the cellular responses of human endothelial cells, the present study first examined the ability of ETR to regulate cell proliferation in HUVECs. ETR treatment suppressed cell proliferation in a dose-dependent manner (Fig. 1A) and did not alter cell viability (Fig. 1C), indicating that ETR inhibition of endothelial cell proliferation was not mediated by induction of apoptosis or cytotoxicity. Based on these results, the present study subsequently analyzed the alterations in the expression level of cell cycle-associated proteins, Cdks, cyclins and pRb in ETR-treated HUVECs. Phosphorylation of $\mathrm{pRb}$ by Cdk/cyclin complexes is essential for the transition from the $G_{1}$ to the $S$ phase of the cell cycle (27). As presented in Fig. 1B, ETR treatment markedly reduced the expression levels of Cdk2 and cyclin E, which induced inhibition of $\mathrm{pRb}$ phosphorylation in response to mitogenic stimulation. These results demonstrated that ETR downregulated the expression level of cell cycle-associated proteins, resulting in inhibition of cell cycle progression and cell proliferation in HUVECs.

ETR inhibits endothelial cell adhesion, migration, invasion and capillary structure formation. The effect of ETR on endothelial cell adhesion, migration, invasion and tube formation was analyzed, which all serve important roles in cancer and angiogenesis-associated diseases (2). As presented in Fig. 2, ETR treatment dose-dependently reduced cell adhesion in HUVECs. In addition, ETR significantly inhibited cell migration, cell invasion (Fig. 3A and B, respectively) and tube formation in HUVECs (Fig. 4). Collectively, these results suggested that the pharmacological roles of ETR in regulating endothelial cell adhesion, migration, invasion and tubular
A
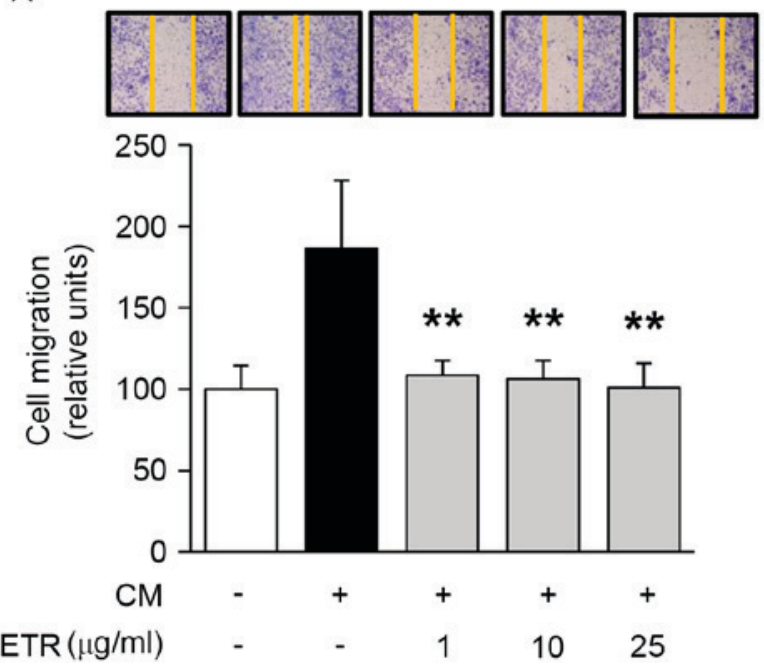

B
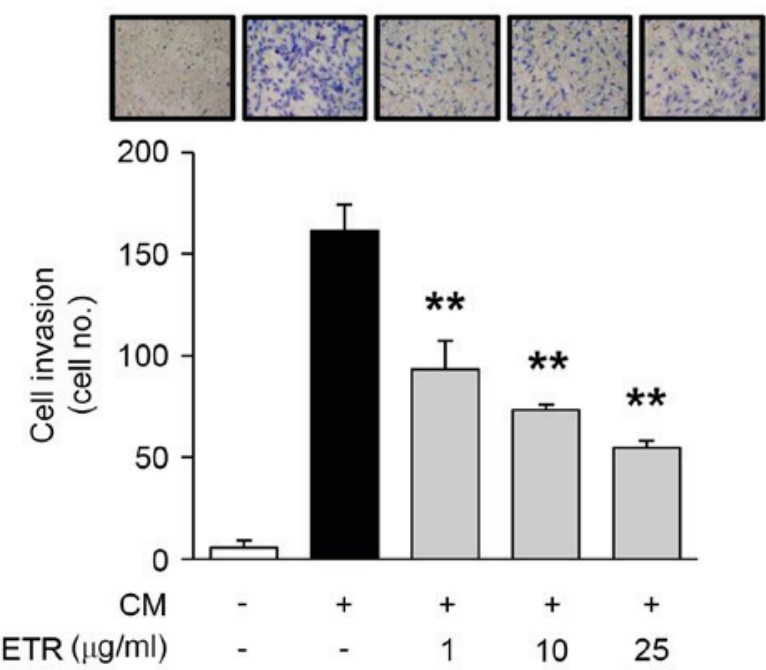

Figure 3. ETR inhibits mitogen-induced migration and invasion in human umbilical vein endothelial cells. (A) Cell migration was quantified by evaluating the migration distance of cells from the wound edge. Cells were incubated for $15 \mathrm{~h}$ in CM with or without ETR (1, 10 and $25 \mu \mathrm{g} / \mathrm{ml})$. Results from six independent experiments (mean \pm standard deviation) are presented as the evaluation of migrated cells. (B) In vitro Transwell invasion was performed. Cells were incubated for $18 \mathrm{~h}$ in $\mathrm{CM}$ with or without ETR $(1,10$ and $25 \mu \mathrm{g} / \mathrm{ml})$. The number of invasive cells was determined by counting six fields of cells (magnification, x200). Results from six independent experiments (mean \pm standard deviation) are presented as the number of invasive cells. Statistical significance is indicated ${ }^{(* *} \mathrm{P}<0.01$, compared with CM-treated cells). ETR, ethanolic extract of Trigonostemon reidioides; $\mathrm{CM}$, complete medium.

formation resulted in the regulation of angiogenic responses in vitro.

Anti-angiogenic activities of ETR are mediated by inhibition of mitogenic signaling pathways and downregulation of MMP-2. In order to further investigate the molecular mechanisms underlying the ETR-mediated regulation of mitogen-induced endothelial cell proliferation, adhesion, migration, invasion and tubular formation, the present study examined the alterations in activation of mitogenic signaling pathways, including ERK, PI3K/Akt 


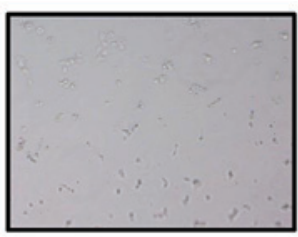

Basic EBM-2

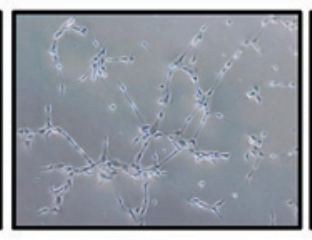

$\mathrm{CM}$

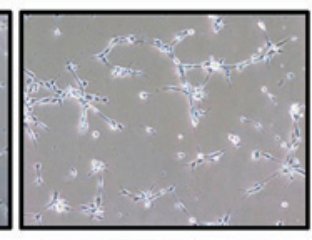

$\mathrm{CM}+\mathrm{ETR} 1 \mu \mathrm{g} / \mathrm{ml}$

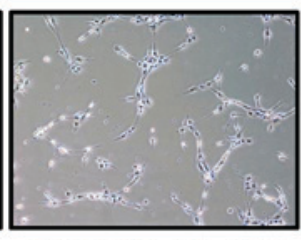

CM+ETR $10 \mu \mathrm{g} / \mathrm{ml} \quad$ CM+ETR $25 \mu \mathrm{g} / \mathrm{ml}$
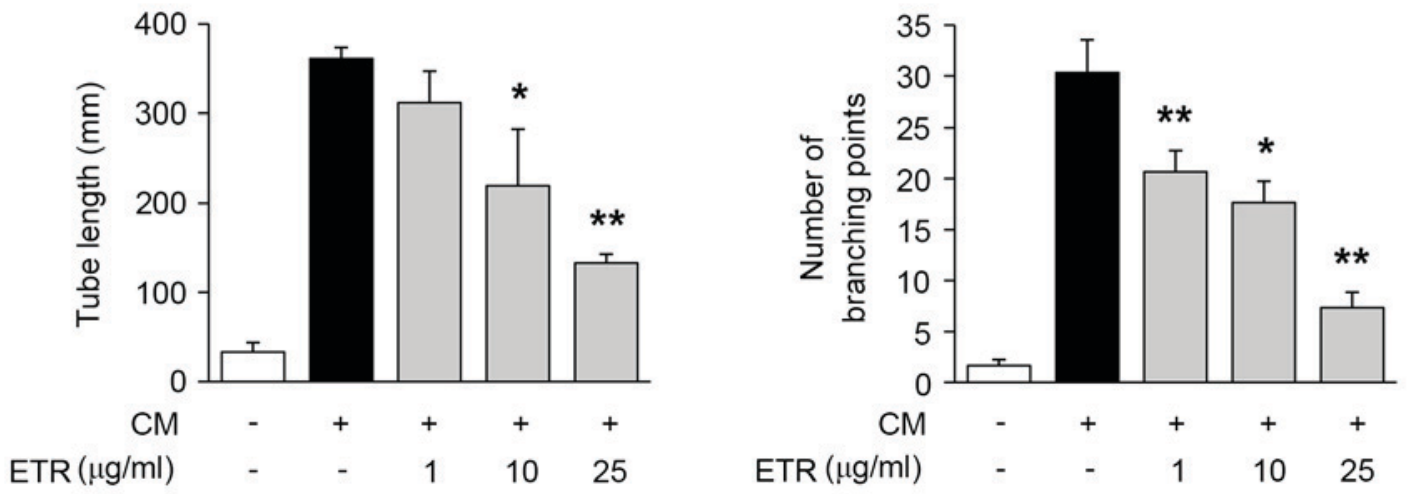

Figure 4. ETR inhibits mitogen-induced formation of capillary structures in HUVECs. Tube formation was quantified by determining the lengths of tubes and numbers of branching points per unit area. Cells were incubated for $4 \mathrm{~h}$ in CM with or without ETR (1, 10 and $25 \mu \mathrm{g} / \mathrm{ml})$. Images were captured using x 200 objective magnification by a Nikon Digital Sight DS-U1 microscope. Results are representative of $\geq 3$ independent experiments (mean \pm standard deviation). Statistical significance is indicated $\left({ }^{*} \mathrm{P}<0.05,{ }^{* *} \mathrm{P}<0.01\right.$, compared with CM-treated cells). ETR, ethanolic extract of Trigonostemon reidioides; CM, complete medium; HUVECs, human umbilical vein endothelial cells.

A

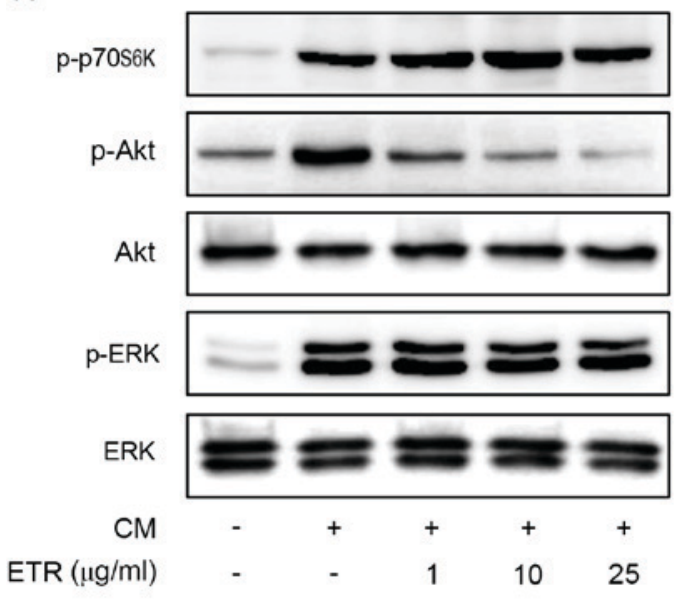

B

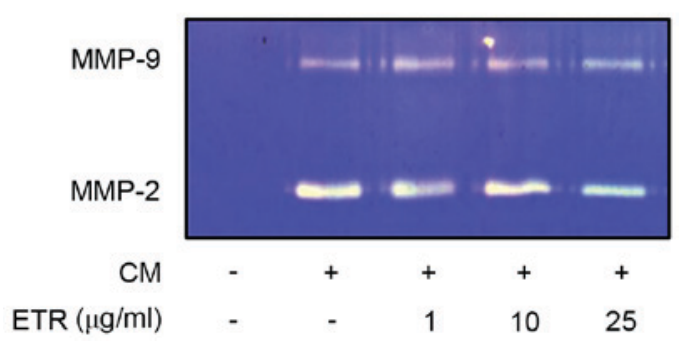

Figure 5.ETR inhibits mitogen-induced Akt and MMP-2 activities. Quiescent cells were treated with ETR $(1,10$ and $25 \mu \mathrm{g} / \mathrm{ml})$ for $15 \mathrm{~min}$. (A) Cell lysates were analyzed by western blotting with anti-p-ERK, anti-ERK, anti-p-Akt, anti-Akt, and anti-p-p70S6K antibodies. (B) Gelatin zymogram analysis was performed using basic EBM 2 medium from cell culture. Zymogram gel loading was normalized to total protein concentration. Results are representative of $\geq 3$ independent experiments. ETR, ethanolic extract of Trigonostemon reidioides; $\mathrm{CM}$, complete medium; MMP, matrix metalloproteinase; p, phosphorylated; ERK, extracellular signal-regulated kinase; p70S6K, p70 ribosomal S6 kinase. and mammalian target of rapamycin/p70S6K, which serve pivotal roles in cellular fate (28). As presented in Fig. 5A, ETR treatment markedly inhibited mitogen-induced phosphorylation/activation of Akt but not of ERK or p70S6K in HUVECs when compared with that in unstimulated control cells. Activation of MMP-9 and MMP-2 has previously been reported to promote endothelial cell migration, invasion and tube formation $(2,3,8)$. In order to confirm the regulatory effects of ETR on endothelial cell migration, invasion and tube formation, the present study subsequently analyzed the changes in activation of MMP-9 and MMP-2. As presented in Fig. 5B, ETR treatment $(25 \mu \mathrm{g} / \mathrm{ml})$ inhibited mitogen-induced activation of MMP-2 in CM of HUVECs. Conversely, the activation of MMP-9 in HUVECs was not altered by ETR treatment. Taken together, these results demonstrated that the inhibitory effects of ETR on endothelial cell proliferation, adhesion, migration, invasion and tube formation may be mediated by inactivation of the PI3K/Akt signaling pathway and subsequent downregulation of MMP-2.

\section{Discussion}

Previous studies have demonstrated that TR contained bioactive compounds, including trigonostemone, a phenanthrenone, and lotthanongine, a novel flavonoidal indole alkaloid $(29,30)$. Previously, novel daphnane diterpenes, namely rediocides A-F (1-6), were isolated from TR and exhibited potent anti-flea activity (31-33). These diterpenes are effective antiviral (human immunodeficiency virus-1) agents, and have been reported to have antileukemic, antimycobacterial and anticancer activities (34-36). In addition, these compounds have may exert anticancer effects via cytotoxicity against various cancer cell lines, including liver, cervical, oral, colon, lung and gastric cancer cell lines (21). However, the effects and 
molecular mechanisms underlying TR on angiogenesis have not been reported to date.

Dysregulation of the PI3K/Akt signaling pathway is closely associated with angiogenesis-associated diseases, including cancer $(9,10)$. The PI3K/Akt signaling pathway serves pivotal roles in the growth, migration and formation of blood vessels in endothelial cells $(11,12)$. Our group has previously reported that the ethanolic extracts of Ligularia fischeri and Broussonetia kazinoki inhibited the proliferation, invasion and tube formation of endothelial cells by inactivation of the mitogen- and VEGF-A-stimulated signaling pathways, including the PI3K/Akt signaling pathway $(37,38)$. To the best of our knowledge, the present study demonstrated for the first time that ETR inhibited mitogen-induced endothelial cell proliferation, adhesion, migration, invasion and tube formation. These anti-angiogenic activities of ETR were mediated by the downregulation of mitogen-induced Cdks/cyclins, and the inhibition of phosphorylation/activation of $\mathrm{pRb}$, Akt and MMP-2, but not of ERK, p70S6K or MMP-9. These results confirmed the possibility of ETR as a novel anti-angiogenic agent that selectively targets the Akt signaling pathway.

In conclusion, the results of the present study provided pharmacological roles and mechanisms of ETR in the regulation of angiogenesis, and warranted further evaluation and development of ETR for the prevention and treatment of diseases associated with angiogenesis.

\section{Acknowledgements}

The present study was supported by the National Institute of Biological Resources under the Ministry of Environment of the Republic of Korea (grant no. 2014-04-202).

\section{References}

1. Cristofanilli M, Charnsangavej C and Hortobagyi GN: Angiogenesis modulation in cancer research: Novel clinical approaches. Nat Rev Drug Discov 1: 415-426, 2002.

2. Folkman J: Angiogenesis: An organizing principle for drug discovery? Nat Rev Drug Discov 6: 273-286, 2007.

3. Carmeliet $P$ and Jain RK: Principles and mechanisms of vessel normalization for cancer and other angiogenic diseases. Nat Rev Drug Discov 10: 417-427, 2011.

4. Cook KM and Figg WD: Angiogenesis inhibitors: Current strategies and future prospects. CA Cancer J Clin 60: 222-243, 2010.

5. Jain RK, Duda DG, Clark JW and Loeffler JS: Lessons from phase III clinical trials on anti-VEGF therapy for cancer. Nat Clin Prac Oncol 3: 24-40, 2006.

6. Ng EW, Shima DT, Calias P, Cunningham ET Jr, Guyer DR and Adamis AP: Pegaptanib, a targeted anti-VEGF aptamer for ocular vascular disease. Nat Rev Drug Discov 5: 123-132, 2006.

7. Brown DM and Regillo CD: Anti-VEGF agents in the treatment of neovascular age-related macular degeneration: Applying clinical trial results to the treatment of everyday patients. Am J Ophthalmol 144: 627-637, 2007.

8. Ellis LM and Hicklin DJ: VEGF-targeted therapy: Mechanisms of anti-tumour activity. Nat Rev Cancer 8: 579-591, 2008.

9. Coffer PJ, Jin J and Woodgett JR: Protein kinase B (c-Akt): A multifunctional mediator of phosphatidylinositol 3-kinase activation. Biochem J 335: 1-13, 1998.

10. Kandel ES and Hay N: The regulation and activities of the multifunctional serine/threonine kinase Akt/PKB. Exp Cell Res 253: 210-229, 1999.

11. Ackah E, Yu J,Zoellner S, Iwakiri Y, Skurk C, Shibata R, Ouchi N, Easton RM, Galasso G, Birnbaum MJ, et al: Akt1/protein kinase $\mathrm{B}$ is critical for ischemic and VEGF-mediated angiogenesis. J Clin Invest 115: 2119-2127, 2005.
12. Yang XM, Wang YS, Zhang J, Li Y, Xu JF, Zhu J, Zhao W, Chu DK and Wiedemann P: Role of PI3K/Akt and MEK/ERK in mediating hypoxia-induced expression of HIF-1alpha and VEGF in laser-induced rat choroidal neovascularization. Invest Ophthalmol Vis Sci 50: 1873-1879, 2009.

13. You JJ, Yang CH, Yang CM and Chen MS: Cyr61 induces the expression of monocyte chemoattractant protein-1 via the integrin $\alpha v \beta 3$, FAK, PI3K/Akt and NF- $\kappa \mathrm{B}$ pathways in retinal vascular endothelial cells. Cell Signal 26: 133-140, 2014.

14. Di Y, Zhang Y, Nie Q and Chen X: CCN1/Cyr61-PI3K/AKT signaling promotes retinal neovascularization in oxygen-induced retinopathy. Int J Mol Med 36: 1507-1518, 2015.

15. Clark AS, West K, Streicher S and Dennis PA: Constitutive and inducible Akt activity promotes resistance to chemotherapy, trastuzumab, or tamoxifen in breast cancer cells. Mol Cancer Ther 1: 707-717, 2002.

16. Knuefermann C, Lu Y, Liu B, Jin W, Liang K, Wu L, Schmidt M, Mills GB, Mendelsohn J and Fan Z: HER 2/PI-3K/Akt activation leads to a multidrug resistance in human breast adenocarcinoma cells. Oncogene 22: 3205-3212, 2003.

17. Katso R, Okkenhaug K, Ahmadi K, White S, Timms J and Waterfield MD: Cellular function of phosphoinositide 3-kinases: Implications for development, homeostasis, and cancer. Annu Rev Cell Dev Biol 17: 615-675, 2001.

18. Tempeam A, Thasana N, Pavaro C, Chuakul W, Siripong P and Ruchirawat S: A new cytotoxic daphnane diterpenoid, rediocide G, from Trigonostemon reidioides. Chem Pharm Bull (Tokyo) 53: 1321-1323, 2005.

19. Biodiversity of Cambodia, Cardamom protected forest and Seima biodiversity conservation area. NIBR, pp 164, 2012

20. Chuakul W, Saralump P and Prathanturarug S: Medicinal Plants in Thailand. Vol. 2. Amarin Printing and Publishing Public Co., Ltd., Bangkok, 1997.

21. Tempeam A, Thasana N, Thavornkitcharat A, Pavaro C and Ruchirawat S: In vitro cytotoxicity of some Thai medicinal plants and daphnane diterpenoid from Trigonostemon redioides. Mahidol U J Pharm Sci 29: 25-31, 2002.

22. Seo DW, Kim SH, Eom SH, Yoon HJ, Cho YR, Kim PH, Kim YK, Han JW, Diaz T, Wei BY and Stetler-Stevenson WG: TIMP-2 disrupts FGF-2-induced downstream signaling pathways. Microvasc Res 76: 145-151, 2008.

23. Seo DW, Li H, Qu CK, Oh J, Kim YS, Diaz T, Wei B, Han JW and Stetler-Stevenson WG: Shp-1 mediates the antiproliferative activity of tissue inhibitor of metalloproteinase-2 in human microvascular endothelial cells. J Biol Chem 281: 3711-3721, 2006.

24. Cho YR, Kim SH, Ko HY, Kim MD, Choi SW and Seo DW: Sepiapterin inhibits cell proliferation and migration of ovarian cancer cells via down-regulation of p70S6K-dependent VEGFR-2 expression. Oncol Rep 26: 861-867, 2011.

25. Cho YR, Choi SW and Seo DW: The in vitro antitumor activity of Siegesbeckia glabrescens against ovarian cancer through suppression of receptor tyrosine kinase expression and the signaling pathways. Oncol Rep 30: 221-226, 2013.

26. Lee HN, Joo JH, Oh JS, Choi SW and Seo DW: Regulatory effects of Siegesbeckia glabrescens on non-small cell lung cancer cell proliferation and invasion. Am J Chin Med 42: 453-463, 2014

27. Harbour JW, Luo RX, Santi AD, Postigo AA and Dean DC: Cdk phosphorylation triggers sequential intramolecular interactions that progressively block Rb functions as cells move through G1. Cell 98: 859-869, 1999.

28. Lemmon MA and Schlessinger J: Cell signaling by receptor tyrosine kinases. Cell 141: 1117-1134, 2010.

29. Kokpol U, Thebpatiphat S, Boonyaratavej S, Chedchuskulcai V, Ni CZ, Clardy J, Chaichantipyuth C, Chittawong V and Miles DH: Structure of trigonostemone, a new phenanthrenone from the Thai plant Trigonostemon reidioides. J Nat Prod 53: 1148-1151, 1990.

30. Kanchanapoom T, Kasai R, Chumsri P, Kraisintu K and Yamasaki K: Lotthanongine, an unprecedented flavonoidal indole alkaloid from the roots of Thai medicinal plant, Trigonostemon reidioides. Tetrahedron Lett 43: 2941-2943, 2002.

31. Jayasuriya H, Zink DL, Singh SB, Borris RP, Nanakorn W, Beck HT, Balick MJ, Goetz MA, Slayton L, Gregory L, et al: Structure and stereochemistry of rediocide A, a highly modified daphnane from Trigonostemon reidioides exhibiting potent insecticidal activity. J Am Chem Soc 122: 4998-4999, 2000 . 
32. Jayasuriya H, Zink DL, Borris RP, Nanakorn W, Beck HT, Balick MJ, Goetz MA, Gregory L, Shoop WL and Singh SB Rediocides B-E, potent insecticides from Trigonostemon reidioides. J Nat Prod 67: 228-231, 2004.

33. Soonthornchareonnon N, Sakayarojkul M, Isaka M, Mahakittikun V, Chuakul W and Wongsinkongman P: Acaricidal daphnane diterpenoids from Trigonostemon reidioides (KURZ) CRAIB roots. Chem Pharm Bull (Tokyo) 53: 241-243, 2005.

34. He W, Cik M, Appendino G, Puyvelde LV, Leysen JE and De Kimpe N: Daphnane-type diterpene orthoesters and their biological activities. Mini Rev Med Chem 2: 185-200, 2002.

35. Pettit GR, Ducki S, Tan R, Gardella RS, McMahon JB, Boyd MR, Pettit GR III, Blumberg PM, Lewin NE, Doubek DL, et al: Isolation and structure of pedilstatin from a republic of maldives Pedilanthus sp. J Nat Prod 65: 1262-1265, 2002.

36. Chumkaew P, Karalai C, Ponglimanont $C$ and Chantrapromma K: Antimycobacterial activity of phorbol esters from the fruits of Sapium indicum. J Nat Prod 66: 540-543, 2003.
37. Kim JH, Kim HJ, Kim JK, Ahn EK, Ko HJ, Cho YR, Lee SJ, Bae GU, Kim YK, Park JW, et al: Ligularia fischeri inhibits endothelial cell proliferation, invasion and tube formation through the inactivation of mitogenic signaling pathways and regulation of vascular endothelial cadherin distribution and matrix metalloproteinase expression. Oncol Rep 34: 221-226, 2015.

38. Cho YR, Kim JH, Kim JK, Ahn EK, Ko HJ, In JK, Lee SJ, Bae GU, Kim YK, Oh JS, et al: Broussonetia kazinoki modulates the expression of VEGFR-2 and MMP-2 through the inhibition of ERK, Akt and p70S6K-dependent signaling pathways: Its implication in endothelial cell proliferation, migration and tubular formation. Oncol Rep 32: 1531-1536, 2014. 